\title{
Factors Affecting International Transfer of Kaizen
}

\author{
Kodo Yokozawa \\ School of Management and Governance, University of Twente, \\ PO Box 715, 7500 AE, Enschede, The Netherlands \\ Email: k.yokozawa@utwente.nl \\ Harm-Jan Steenhuis \\ College of Business and Public Administration, Eastern Washington University \\ 668 N. Riverpoint Blvd., Suite A, Spokane, WA 99202, USA \\ E-mail: hsteenhuis@mail.ewu.edu \\ Erik-Joost de Bruijn \\ School of Management and Governance, University of Twente, \\ PO Box 715, 7500 AE, Enschede, The Netherlands \\ E-mail: e.j.debruijn@utwente.nl
}

\begin{abstract}
So far, the literature on the international transfer of kaizen is inconclusive with regard to what influences successful transfer. The purpose of this study is to contribute to the literature by studying the influence of organization structure and culture. Furthermore, since kaizen is ambiguously used, another purpose it to determine whether personal initiative is related to kaizen. The study was interview oriented and conducted at Japanese subsidiaries in the Netherlands. The results indicate that organic structures and clan-oriented cultures are the best for kaizen transfer whereas hierarchical cultures are not conducive to successful kaizen transfer. Furthermore, it was found that personal initiative is positively correlated with kaizen.
\end{abstract}

Keywords: Kaizen; technology transfer; personal initiative; organizational structure; organizational culture

\section{Introduction}

Kaizen is generally defined as continuous improvement involving people in all level of organisation (Imai, 1986). The concept of continuous improvement was originally developed in the USA and transferred to Japan after the Second World War (Bhuiyan \& Baghel, 2005). It was adapted and further enhanced by Japanese companies and the Japanese provided a Japanese name for it; kaizen (Kenney \& Florida, 1993; Oliver \& Wilkinson, 1992). The concept was crystallized in Toyota (Ohno, 1988), and spread among other Japanese manufacturers as Toyota gained fame in international markets for high quality products. Since other companies also improved their performance, it has been viewed as a key component in Japanese management and has been presented as one of the sources of the competitiveness of Japanese manufacturers (Imai, 1986; Kenney and Florida, 1993; Oliver and Wilkinson, 1992).

In recent years, studies have been conducted on the transfer of Japanese production systems, including kaizen, to other countries. For example, Hong et al. (2006), Taylor (1999), and Aoki (2008) examined the transferability of Japanese practices to China. Saka (2004) and Oliver \& Wilkinson (1992) examined the diffusion of Japanese operations, including kaizen, to the UK while Kenney \& Florida (1993) looked at the transfer to the US. The results of 
studies on success of kaizen transfer are mixed. Fukuda (1988), Kono (1982), and White \& Trevor (1983) found that kaizen was not successfully transferred. In contrast, Adler et al. (1998) found that kaizen was successfully transferred, in particular at NUMMI, a Toyota/General Motors joint venture.

The purpose of this study is to provide additional insight into factors that affect the successful international transfer of kaizen.

\section{Conceptual research framework}

In this section, the conceptual research framework is developed. The research framework is oriented on increasing understanding of the term kaizen (2.1) as well as identifying specific factors that influence the transfer of kaizen (2.2).

\subsection{Proxy of kaizen: personal initiative}

A first difficulty for studying the transfer of kaizen is the ambiguousness of the term kaizen. Brunet \& New (2003) conclude that the term kaizen is inconsistently used and there is no universal definition that authors adopt. This means that although a variety of studies explicitly look at the transfer of kaizen, they may actually be dealing with different things. One objective of this study is to contribute to a better understanding of kaizen.

Kaizen has been discussed in association with continuous improvement. For example, Imai (1986: p. xxix) defines it as "ongoing improvement involving everyone - top management, managers, and workers". Other authors share this view of equating kaizen with continuous improvement explicitly (Aoki, 2008; Malloch, 1997; Styhre, 2001) or implicitly (Bessant et al., 2001; Dobosz-Bourne \& Jankowicz, 2006; Jørgensen et al., 2003). Brunet \& New (2003) discuss the ambiguity and inconsistency of the way kaizen is described in the literature. They define kaizen as "consist of pervasive and continual activities, outside the contributor's explicit contractual roles, to identify and achieve outcomes he believes contribute to the organizational goals" (Brunet \& New, 2003: 1428). A similar idea has been mentioned by Hayashi (1994), that is, in Japanese organizations a person's job description is not clearly defined and often overlaps. This vagueness weakens the notion of individual responsibility and promotes the notion of group responsibility. As a result, it is easier to go beyond formal responsibility. Thus, it can be concluded that kaizen relates to continuous improvement activities by employees where these activities go beyond the contractual role.

Another concept with a similar emphasis on employee responsibility is the concept of personal initiative. Personal initiative is defined as a behavioral pattern whereby individuals take an active, self-starting approach to work and go beyond formal job requirements (Frese et al., 1996; Frese et al., 1997). The general actions for people with personal initiative includes, identifying opportunities to improve things, challenging the status quo, and creating favorable conditions. Frese \& Fay (2001) mentioned that personal initiative is characterized by five components: 1) alignment with the organizational mission; 2) longterm focus; 3 ) action-oriented and goal directed; 4) persistent in the face of obstacles; and 5) self-starting and proactive.

Many characteristics of kaizen and personal initiative show commonality. For example, both concepts include activities that are outside the employee's role and persistence in identifying and solving problems that are consistent with the organizational goal. It can therefore be argued that the measurement of kaizen, which as was discussed above has been ambiguous, can potentially be accomplished by measuring personal initiative. The advantage of this is that the concept of personal initiative has already been operationalized and measured. Therefore, to contribute towards consistency on the definition of kaizen a first hypothesis was stated as:

Hypothesis 1: Employees' personal initiative at work is positively associated with successful transfer of kaizen.

\subsection{Factors that influence kaizen transfer}

Imai (1986) indicated that kaizen is an umbrella concept covering most of the famous Japanese management systems. Factors that influence the transfer of Japanese management systems are potentially valid for the transfer of kaizen as well. The literature review was therefore not limited to factors that affect kaizen transfer but broadened to factors that affect Japanese management system transfer. This led to the identification of two main factors: organization structure (2.2.1) and organization culture (2.2.2). 


\subsubsection{Organization structure}

Saka (2004) studied the transfer of Japanese work systems, including kaizen, to Japanese subsidiaries in the UK. Her focus was on companies in the automotive industry. She found that the degree to which systems were transferred differed by company. She notes: “...the operational autonomy provided to individuals in small-group activities, strengthened by a sense of 'groupism' in large firms in the Japanese automotive industry, conflicts with the low worker discretion and sense of individualism that has traditionally strengthened the management hierarchy in the UK automotive industry" (Saka, 2004: 221). This points to how companies are organized or structured.

Various studies have shown that job classification tends to be much simpler and broader in Japanese manufacturing firms compared with American firms (Cole, 1979; Kenney \& Florida, 1993). Kenney \& Florida (1993) find that Japanese organize work on the basis of just a few job classifications. For example, there are four job classifications for production workers at Nissan and NUMMI, three at Honda and Toyota, and only two at Mazda and SIA. This is significantly different from the traditional U.S. production organization where virtually every job has its own job classification, and where those job classifications are seen by workers and unions to provide the basis for wage increases and employment security (Aoki, 1988; Koike, 1998; Shimada, 1990).

Aside from a focus on job classifications, the literature on organization structure identifies various aspects of structure. Main aspects identified in the literature are: the degree of specialization, the degree of centralization, the degree of formalization, the degree of standardization, and the degree of configuration (Blau, 1968; Inkson et al., 1970; Pugh et al., 1968; Reimann, 1974). Burns \& Stalker (1961) suggest that the nature of organizational structure could be viewed as comprising one main dimension which distinguishes mechanistic versus organic organizations. Saka's (2004) findings suggest that a prime difference between the Japanese and UK companies was the more mechanistic organization structures of the UK companies compared to the more organically oriented Japanese companies. Hayashi (1994) also found that Japanese organizations tend to have organic organizational structures.

A mechanistic form of organization is appropriate for stable environmental conditions. It is characterized by a high degree of formalization and centralization, and a clear hierarchy of control in which responsibility for overall knowledge and control rests at the top. The tasks of management are broken down into specialism, with individuals carrying out the assigned and defined tasks. Vertical communication is prominent and there is a requirement for loyalty to superiors. In comparison, an organic form of organization is appropriate for dynamic environmental conditions, that is when new and unexpected problems continually emerge, and where problems cannot be divided and assigned among the different specialism. In organic organizations, there is continual adaptation and redefining of individual tasks and a supportive rather than restrictive nature of specialist knowledge is emphasized. Communication and interaction can take place at any level, as determined by the need of a process, and there exists a much higher degree of commitment to the organization than for the mechanistic organization.

A mechanistic structure leads to a different approach to business compared to the organic structure. For example, when a problem occurs in an organic organization there is no specific individual who covers it because of the vague job descriptions. Consequently, several people who are affected by the problem will share information to tackle the problem together. In contrast, in a mechanistic organization, responsibility is more clearly defined. In cases where a problem occurs in an area where responsibility is not (yet) defined, then people discuss and decide who should be responsible. In mechanistic organization structures it is therefore more difficult for employees to go beyond their job responsibility. Since kaizen relates to conducting activities that fall outside of the formal job description (Brunet \& New, 2003: 1428), this leads to the second hypothesis:

Hypothesis 2: Organically-structured firms are more successful with transferring kaizen than mechanistically-structured firms.

\subsubsection{Organization culture}

Aside from organization structure, culture has been identified as another important variable affecting the kaizen transfer process (Fukuda, 1988; Kono, 1982; Ouchi \& Jaeger, 1978; White \& Trevor, 1983). Lillrank (1995) indicated that direct transfers of Japanese innovation practices often fail not because of 
geographical distance but rather due to the mental distance, i.e. culture, history and strategic paradigms. Aoki (2008) also notes that "the implementation of Japanese kaizen activities in overseas plants is situated in the cultural and social contexts" (Aoki, 2008: 519). Recht \& Wilderom (1998) examined the existing literature on the transferability of kaizen oriented suggestion systems with an emphasis on the influence of cultural characteristics. Recht \& Wilderom (1998: 11) point out that kaizen oriented suggestion systems are oriented on intrinsic value, that is, although in Japan some rewards are provided, these are of symbolic nature. They conclude that the main strategy of Japanese companies which set up factories abroad is to minimize cultural conflict, for example by setting up greenfield plants. Another important notion is that for kaizen implementation to be successful it is important that an organizational culture exists where operators can admit their mistakes (Imai, 1986; Ohno, 1988; Wakamatsu, 2007). Based on the above, it can be concluded that culture plays a role in the transfer of kaizen. But the question remains how culture affects kaizen transfer.

Culture can be defined as the "collective programming of the mind" (Hofstede, 2001). For this study it is important to identify specific cultural characteristics, i.e. those that potentially influence the ease with which kaizen can be transferred. In this research the competing values model is used (Quinn \& Rohrbaugh, 1981). Quinn \& Rohrbaugh's (1981) research showed that models of organizational effectiveness could be distinguished along two axes reflecting different value orientations. One axis distinguishes flexibility and discretion versus stability and control. The other axis has an internalexternal focus dimension. This distinction results in four quadrants for organizational culture: clan, adhocracy, hierarchic, and market.

Clan culture: The clan culture emphasizes flexibility and maintains a focus on the internal organization. This culture has a primary concern with human relations. The purpose of organizations with an emphasis on clan culture tends to be group maintenance and belonging, trust and participation are core values. Primary motivational factors include attachment, cohesiveness, and membership. Looking at the Toyota culture can provide insights for a suitable corporate culture for kaizen development since Toyota is an initiator of kaizen and has successfully sustained kaizen among workers (Bessant et al., 2001; Imai, 1986; Monden, 1994; Ohno, 1988; Wakamatsu, 2007). Toyota's corporate culture can be described by a group oriented and egalitarian corporate culture, i.e. similarities with the clan culture. Individuals develop identification with a group and a sense of 'community of fate', and believe that all share a common destiny with one another (Cole, 1979; Ohno, 1988). Toyota attaches significance to workers' loyalty to their companies and cultivates a sense of togetherness among them. Company uniforms, songs, morning exercises, after work social gatherings, and ceremonies are organizational mechanisms used to sustain and build Toyota's culture (Besser, 1996; Kenney \& Florida, 1993; Liker, 2004; Shimada, 1990). Mutual trust among employees promotes employees' willingness to interchange or apply their knowledge and responsibilities without restrictions (Recht \& Wilderom, 1998). In summary, a corporate culture that focuses on the internal improvement, grouporientation, human resource orientation, belonging, trust, and participation can be considered suitable for developing kaizen. This leads to the following hypothesis:

Hypothesis $3 a$ A higher degree of clan organizational culture leads to more success with kaizen transfer.

Adhocracy culture: The adhocracy culture emphasizes flexibility and change, but maintains a primary focus on the external environment. This cultural orientation emphasizes growth, resource acquisition, creativity, and adaptation to the external environment. Key motivating factors include growth, stimulation, creativity, and variety. The characteristics of this culture which emphasize change match with kaizen development. For example, Toyota put its emphasis on flexibility and small and continuous changes. Katsuaki Watanabe, the former CEO of Toyota, described the corporate culture of Toyota as "No change is bad" in a sense that everyone should not be satisfied with the status quo but should be trying to improve the situation all of the time (Osono et al., 2008). Although Toyota has primary concerns with human relations and group culture, they put equal emphasis on the adaptation of the external environment. Toyota's top management maintains a focus on environmental 
changes and expresses a sense of urgency which then generates a culture for continuous change in the organization (Liker, 2004). For these reasons, it can be argued that an adhocracy organizational culture is also good for the development of kaizen. This leads to the following hypothesis:

\section{Hypothesis 3b: A higher degree of adhocracy culture leads to more success with kaizen transfer.}

Hierarchical culture: The hierarchical culture emphasizes internal efficiency, uniformity, coordination, and evaluation. The purpose of the organization with an emphasis on the hierarchical culture tends to be the execution of regulations. Motivating factors include security, order, rules, and regulations. Leaders are conservative and cautious, paying close attention to technical matters. Effectiveness criteria include control, stability, and efficiency.

The underlying philosophy of kaizen requires employees to identify and diagnose quality problems and take corrective action without going through the management hierarchy (Besser, 1996; Cole, 1979; Imai, 1986; Wakamatsu, 2007). Teamwork and mutual trust among workers are critical for kaizen development. In companies that have mainly vertical coordination and control channels, it is less likely that teamwork develops. This in turn makes it difficult to develop mutual trust among workers. For these reasons it can be inferred that hierarchical culture is not suitable for kaizen development. Thus:

\section{Hypothesis 3c: A higher degree of hierarchical culture leads to less success with kaizen transfer.}

Market culture: The market culture emphasizes productivity, performance, goal fulfillment, and achievement. The purpose of organizations with an emphasis on the market culture tends to be the pursuit and attainment of well-defined objectives. Motivating factors include competition and the successful achievement of predetermined ends. Leaders tend to be directive, goal oriented, instrumental, and functional, and are consistently providing structure and encouraging productivity. Effectiveness criteria include planning, productivity and efficiency. For these companies, pressure for the results comes from those external constituencies, which in turn, makes the company more short-term and explicitly results oriented. In a market culture organization each individual is striving for the result and steep internal competition exists within the corporation (Cameron \& Quinn, 2006).

Competitive and independent goals are likely to undermine relationship development (Deutsch, 1949; Johnson, 1981) which is a critical element of kaizen. Deming (2000: 82) stated, "Harm comes from internal competition and conflict, and from the fear that is thereby generated". Expecting that others are uninterested and may even have an orientation towards obstructing one's goals, individuals and groups undermine relationships and create doubt that they can work together. It can therefore be inferred that a market oriented culture does not lead to the successful kaizen transfer. Therefore:

\section{Hypothesis 3d: A higher degree of market culture leads to less success with kaizen transfer.}

The overall conceptual research framework is graphically represented in figure 1.

\section{Figure 1. Conceptual research framework}

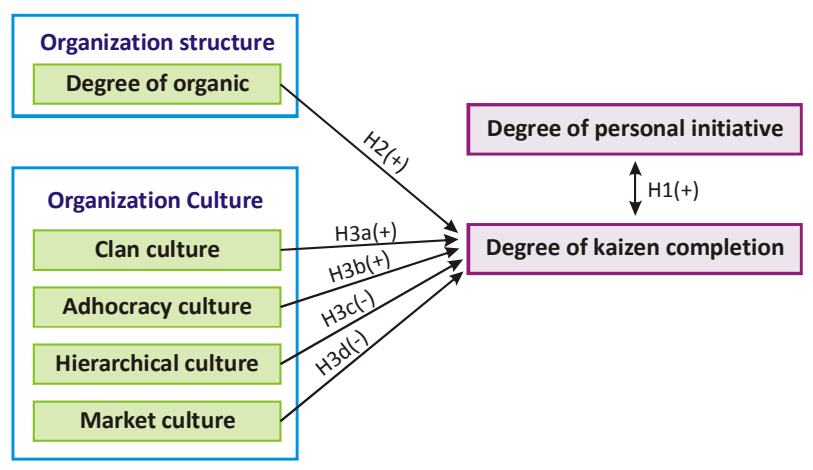

\section{Methodology}

In this section, the methodology is discussed, i.e. the operationalization of the concepts from the conceptual research framework. Section 3.1 describes the concepts and their measurement, section 3.2 the selection of the sample and in section 3.3 the followed procedures are explained. 


\subsection{Measures and analysis}

There are four main concepts identified in the conceptual research framework: degree of personal initiative (3.1.1), organization structure (3.1.2), organization culture (3.1.3) and success with kaizen transfer (3.1.4).

\subsubsection{Degree of personal initiative}

Frese et al. (1997) and Frese et al. (1996) discussed several measures of personal-initiative. One of the issues they described is that measuring self-initiative by means of a survey is subject to social desirability bias and may lead to incorrect conclusions. They followed an interview format that allowed probing in several areas. The same approach was followed in this study.

From Frese et al. (1996) and Frese \& Fay (2000) three measures for personal initiative were adopted. These are overcoming barriers, activeness, and initiative at work. Overcoming barriers is measured through interviewing respondents and confronting them with four difficult situations. For each situation subsequent barriers are introduced. Overall, a score ranging from 1-5 is allocated based on how many barriers are overcome. The activeness measure is related to the overcoming barriers information and in this case a rating of a scale of 1-5 is determined based upon how actively the barriers were overcome. Lastly, a retrospective measure for initiative at work is used where respondents are asked four questions about work situations and what the respondent did. For example about whether they submitted suggestions to improve work during the last year. Two ratings for each question are made. One involves rating how much quantitative initiative was involved (on a scale from 1 to 5), this means how much effort in time it involved. The other rating is how much qualitative initiative was necessary (on a scale from 1-5). This means looking at how much the activity went beyond what is expected from a person in that job. Averaging the ratings per respondent provides an indicator for personal-initiative for a respondent. Combining all respondents gives an indication for overall level of personal-initiative in the organization.

In addition to adopting the existing measures from Frese et al. (1996) and Frese \& Fay (2000), the operator's personal initiative was also measured by asking managers about their perception of the level
Table 1: Measurement of personal initiative

\begin{tabular}{|c|l|}
\hline \multicolumn{1}{|c|}{ Variable } & $\begin{array}{c}\text { Item adopted from Frese et al. (1996) and } \\
\text { Frese and Fay (2000) }\end{array}$ \\
\hline \multirow{3}{*}{$\begin{array}{c}\text { Degree of personal } \\
\text { initiative }\end{array}$} & Overcoming barriers \\
\cline { 2 - 2 } & Activeness \\
\cline { 2 - 2 } & Initiative at work (quantitative and qualitative) \\
\hline
\end{tabular}

of personal initiative at the shopfloor. This measure was added because it was anticipated that the number of operators in the study would be limited. Also, the managers were expected to have a good sense of how much personal initiative exists in general at the factory. This measure was conducted later in the interviews after a definition of personal initiative was provided and asking for an indication of what percentage of employees currently demonstrate personal initiative.

\subsubsection{Organization structure}

For organization structure, the measurement relates to measuring how organic the organization is. The operationalization of this construct was provided by Covin \& Slevin (1988), who adopted Khandwalla's (1977) scales. This approach was also adopted in this study. This measure includes seven questions which are measured on a seven point scale. The ratings on these items were averaged to arrive at a single index for the degree of organic structure of the firm. The higher the score on this measure the more it was oriented to an organic style; the lower the score, the more the top management was oriented towards a mechanistic style.

\subsubsection{Organizational culture}

Following the discussion in section 2.2.2, the competing values culture instrument by Quinn \& Spreitzer (1991) was used in this research. In the competing cultures instrument organization cultures are measured along two dimensions leading to four main groupings of cultures: clan, adhocracy, hierarchic, and market. The measurement is accomplished through measuring four items: company characteristics, company leaders, the "glue" or holding agent, and company emphasis, see table 2. Each item contains a set of four statements and respondents are asked to divide 100 points among these four statements (for each item) to indicate emphasis. The average of these measures 
Table 2: Measurement of organization structure

\begin{tabular}{|c|c|c|}
\hline \multirow{2}{*}{ Variable } & \multicolumn{2}{|c|}{ Items adopted from Covin and Slevin (1988) } \\
\hline & One end of scale (1) & Other end of scale (7) \\
\hline \multirow{7}{*}{$\begin{array}{l}\text { Degree of organic structure } \\
\text { of the firm }\end{array}$} & $\begin{array}{l}\text { Highly structured channels of communication and a highly } \\
\text { restricted access to important financial and operating } \\
\text { information }\end{array}$ & $\begin{array}{l}\text { Open channels of communication with important financial and } \\
\text { operating information flowing quite freely throughout the } \\
\text { business unit }\end{array}$ \\
\hline & $\begin{array}{l}\text { A strong insistence on a uniform managerial style throughout } \\
\text { the business unit }\end{array}$ & $\begin{array}{l}\text { Managers' operating styles allowed to range freely from the } \\
\text { very formal to the very informal }\end{array}$ \\
\hline & $\begin{array}{l}\text { A strong emphasis on giving the most say in decision making } \\
\text { to formal line managers }\end{array}$ & $\begin{array}{l}\text { A strong tendency to let the expert in a given situation have } \\
\text { the most say in decision making even if this means even } \\
\text { temporary bypassing of formal line authority }\end{array}$ \\
\hline & $\begin{array}{l}\text { A strong emphasis on holding fast to tried and true } \\
\text { management principles despite any changes in business } \\
\text { conditions }\end{array}$ & $\begin{array}{l}\text { A strong emphasis on adapting freely to changing } \\
\text { circumstances without too much concern for past practice }\end{array}$ \\
\hline & $\begin{array}{l}\text { A strong emphasis on always getting personnel to follow the } \\
\text { formally laid down procedures }\end{array}$ & $\begin{array}{l}\text { A strong emphasis on getting things done even if it means } \\
\text { disregarding formal procedures }\end{array}$ \\
\hline & $\begin{array}{l}\text { Tight formal control of most operations by means of } \\
\text { sophisticated control and information systems }\end{array}$ & $\begin{array}{l}\text { Loose, informal control; heavy dependence on informal } \\
\text { relationships and the norm of cooperation for getting things } \\
\text { done }\end{array}$ \\
\hline & $\begin{array}{l}\text { A strong emphasis on getting line and staff personnel to adhere } \\
\text { closely to formal job descriptions }\end{array}$ & $\begin{array}{l}\text { A strong tendency to let the requirements of the situation and } \\
\text { the individual's personality define proper on-job behavior }\end{array}$ \\
\hline
\end{tabular}

\section{Table 3: Measurement of organization culture}

\begin{tabular}{|c|c|}
\hline Item & Statements adopted from Quinn and Spreitzer (1991) \\
\hline \multirow{4}{*}{ Company characteristics } & Company W is a very personal place. It is like an extended family. People seem to share a lot of themselves. \\
\hline & Company $\mathrm{X}$ is a very dynamic and entrepreneurial place. People are willing to stick their necks out and take risks. \\
\hline & Company $Y$ is a very formalized and structured place. Bureaucratic procedures generally govern what people do. \\
\hline & Company $\mathrm{Z}$ is very production oriented. A major concern is getting the job done. People aren't personally involved. \\
\hline \multirow{4}{*}{ Company leader } & The head of company $W$ is generally considered to be a mentor, a sage, or a father or mother figure. \\
\hline & The head of company $X$ is generally considered to be an entrepreneur, an innovator, or risk taker. \\
\hline & The head of company $Y$ is generally considered to be a coordinator, organizer, or an administrator. \\
\hline & The head of company Z is generally considered to be a producer, a technician, or a hard-driver. \\
\hline \multirow{4}{*}{$\begin{array}{l}\text { Company "glue" or holding } \\
\text { agent }\end{array}$} & Company $\mathrm{W}$ is held together by loyalty and tradition. Commitment to this company runs high. \\
\hline & Company $\mathrm{X}$ is held together by a commitment to innovation and development. There is an emphasis on being first. \\
\hline & Company $Y$ is held together by formal rules and policies. Maintaining a smooth-running company is important here. \\
\hline & Company $Z$ is held together by an emphasis on tasks and goal accomplishment. A production orientation is commonly shared. \\
\hline \multirow{4}{*}{ Company emphasis } & Company W emphasizes human resources. High cohesion and morale in the company are important. \\
\hline & Company $\mathrm{X}$ emphasizes growth and acquiring new resources. Readiness to meet new challenges is important. \\
\hline & Company Y emphasizes permanence and stability. Efficient, smooth operations are important. \\
\hline & Company Z emphasizes competitive actions and achievement. Measurable goals are important. \\
\hline
\end{tabular}

provides an indication of degree of organizational culture. An emphasis, i.e. more points, on statements relating to company $\mathrm{W}, \mathrm{X}, \mathrm{Y}$ and $\mathrm{Z}$ correspond respectively with an orientation towards the clan, adhocracy, hierarchic and market culture.

\subsubsection{Success with kaizen transfer}

Measures for success with kaizen transfer in terms of Brunet \& New's (2003) definition of kaizen have not been established in the literature. Several authors proposed general measures for kaizen or continuous 
Table 4: Summary of methods applied

\begin{tabular}{|c|c|c|c|c|c|}
\hline \multirow[b]{2}{*}{ Measures } & \multicolumn{2}{|c|}{ Personal initiative } & \multirow{2}{*}{$\begin{array}{c}\text { Degree of } \\
\text { organic structure }\end{array}$} & \multirow{2}{*}{$\begin{array}{c}\text { Degree of } \\
\text { organizational culture } \\
\text { Competing cultures } \\
\text { instrument Quinn \& } \\
\text { Spreitzer (1991) }\end{array}$} & \multirow{2}{*}{$\begin{array}{c}\text { Kaizen transfer } \\
\text { success } \\
\begin{array}{c}\text { Perception in } \\
\text { percentage }\end{array}\end{array}$} \\
\hline & $\begin{array}{c}\text { Perception of } \\
\text { shopfloor operators }\end{array}$ & $\begin{array}{l}\text { Instrument of } \\
\text { Frese et al (1996) }\end{array}$ & & & \\
\hline Managers & $x$ & & $x$ & $x$ & $x$ \\
\hline Operators & & $x$ & $x$ & $x$ & \\
\hline
\end{tabular}

improvement (Claver, Tari, \& Molina, 2003; Douglas \& Judge, 2001) but these proposed general measures have been used more specifically for elements of different constructs such as TQM and quality management and are not developed specifically to measure the concept of kaizen nor the success of its transfer. Moreover, those items do not fit to the definition from Brunet \& New (2003).

In this study, it is assumed that success with kaizen transfer is logically related to accomplishing a higher level of kaizen transfer to the factory. Kaizen completion was measured after providing respondents with the definition of kaizen and asking; "In your perspective, what is the degree of completion of developing kaizen in this factory as a percentage?"

\subsection{Sample}

Data for this research was collected from Japanese manufacturers in the Netherlands. Japanese manufacturers were selected because kaizen has been frequently used as one of the best practices in the Japanese manufacturing industry (Aoki, 2008). Ohmae (1985) argued that for business, there are three important regions in the world, i.e. the triad, which consists of Japan, the US and Europe. In this study, the focus is on kaizen transfer to Europe. Within Europe, a further distinction was made based on where Japanese companies invest. Based on data from the Japan External Trade Organization (JETRO) a choice was made to focus on the Netherlands. For the last seven years, i.e. 2003 until 2009, the Netherlands was the largest recipient in Europe of Japanese investments (http://www.jetro.go.jp/en/reports/ statistics/).

A list of Japanese manufacturers in the Netherlands was obtained from the website of the Netherlands Foreign Investment Agency (NFIA) and a publication from Japan External Trade Organization
(JETRO). These two lists were combined to develop one list of companies leading to one list with 52 Japanese manufacturers operating in the Netherlands. Researchers contacted each company by phone and asked for participation. In the initial stage, it was found that five companies either closed their factory or had transferred their operations to other countries. Out of the remaining 47 companies, 15 companies agreed to cooperate. During the data collection, it was found that one of the companies had recently established a factory in the Netherlands and was not (yet) implementing kaizen. Therefore, a total of 14 companies were included in the analysis.

\subsection{Procedure}

Each company was asked to arrange separate meetings for interviews with the managing director (MD), the production manager, and three to five shopfloor operators. The interviews consisted of a series of open ended questions as well as several closed questions. The closed questions were formulated on separate pieces of paper and the respondents were, after providing a short description, asked to fill these in. They were completed in front of the researcher in a conference room at the company. Table 4 shows the summary of measures used and questions asked to managers and shopfloor operators.

In some companies, the managing director was not able to participate in the interview survey due to their heavy duties. In these instances, they were replaced by another top or middle manager who was deemed to have sufficient knowledge about kaizen and the organization's characteristics. Also, in some companies it was not allowed to interview shopfloor operators. The reason provided was that the operators had extensive duties and could not be missed. Characteristics of the samples are shown in Table 5 below: 
Table 5: List of surveyed plants, respondents and intre-class correlation coefficient

\begin{tabular}{|c|c|c|c|}
\hline Companies & $\begin{array}{c}\text { Size } \\
\text { (employee) }\end{array}$ & Respondents & $\begin{array}{c}\text { Intra-class correlation coefficient } \\
* \star p<0.01 \\
* p<0.05 \\
+p<0.10\end{array}$ \\
\hline A & $500-999$ & $\begin{array}{l}\text { - } 3 \text { middle managers (Dutch). } \\
\text { - } 3 \text { operators (Dutch) }\end{array}$ & Organizational structure $0.91^{\star \star}$ Organizational culture 0.80 ** \\
\hline $\mathrm{B}$ & $100-199$ & $\begin{array}{l}\text { - } \mathrm{MD} \text { (Japanese). } \\
\text { - } 2 \text { middle managers (Japanese) } \\
\text { - } 3 \text { operators (Dutch) }\end{array}$ & Organizational structure $0.70^{\star}$ Organizational culture $0.42 \dagger$ \\
\hline C & $100-199$ & $\begin{array}{l}\text { - MD (Dutch) } \\
\text { - } 3 \text { operators (Dutch) }\end{array}$ & Organizational structure $0.72^{\star}$ Organizational culture $0.85^{\star *}$ \\
\hline D & $\begin{array}{l}200-299 \\
50-99\end{array}$ & $\begin{array}{l}\text { - } M D \text { (Dutch). } \\
\text { - Middle manager (Dutch) } \\
\text { - } 3 \text { operators (Dutch) } \\
\text { - } 2 \text { middle managers (Japanese) } \\
\text { - } 3 \text { operators (Dutch) }\end{array}$ & $\begin{array}{l}\text { Organizational structure } 0.63+\text { Organizational culture } 0.75 \text { ** } \\
\text { Organizational structure } 0.61 † \text { Organizational culture } 0.47 \dagger\end{array}$ \\
\hline $\mathrm{F}$ & $0-49$ & $\begin{array}{l}\text { - MD (Dutch) } \\
\text { - Middle Manager (Dutch) } \\
\text { - } 3 \text { operators (Dutch) }\end{array}$ & Organizational structure $0.70^{\star *}$ Organizational culture 0.79 ** \\
\hline G & $50-99$ & $\begin{array}{l}\text { - } \mathrm{MD} \text { (Japanese) } \\
\text { - } 2 \text { middle managers (Dutch and Japanese) } \\
\text { - } 3 \text { operators (Dutch) }\end{array}$ & Organizational structure $0.87^{\star \star}$ Organizational culture $0.58 \dagger$ \\
\hline $\mathrm{H}$ & $500-999$ & - Middle manager (Japanese) & Not applicable \\
\hline I & $100-199$ & - MD (Japanese) & Not applicable \\
\hline$J$ & $0-49$ & $\begin{array}{l}\text { - } \mathrm{MD} \text { (Japanese) } \\
\text { - } 2 \text { middle managers (Dutch and Japanese) }\end{array}$ & Organizational structure $0.63+$ Organizational culture 0.77 * \\
\hline K & 1000 and more & - Middle managers (Dutch) & Not applicable \\
\hline $\mathrm{L}$ & $0-49$ & - MD (Neither Dutch nor Japanese) & Not applicable \\
\hline M & $50-99$ & - Middle manager (Dutch) & Not applicable \\
\hline $\mathrm{N}$ & $0-49$ & - MD (Japanese) & Not applicable \\
\hline
\end{tabular}

\section{Results and discussion}

Kendall's tau was used to measure a correlation among variables. Kendall's tau is the non-parametric test that is suitable for testing hypothesis with small sample (Hollander \& Wolfe, 1999). Results from the test of the hypotheses are shown in the Table 6 .

Hypothesis 1: The first hypothesis relates the kaizen transfer success and personal initiative. On the one hand, kaizen completion was significantly related to the manager's perspective of personal initiative, $\tau=0.49, n=12, p$ (one-tailed) $<0.05$ level. On the other hand, kaizen completion was not significantly related to the direct measure of operator's personal initiative.
It is possible that this result occurred because the company selected the operators that participated in the study, i.e. there was no control over random selection of operators. The data collected from the operators is therefore subject to bias because they tended to be operators who had certain characteristics (i.e. the best operators in the company). The results from the instruments of Frese et al. (1997) could potentially have been better if operators had been randomly selected and/or if a larger number of operators was interviewed.

This study suggests that the managers' assessment on the personal initiative can be a reliable 
Table 6: Descriptive statistics and correlations (Kendall's $\tau$ )

\begin{tabular}{|c|c|c|c|c|c|c|c|c|c|}
\hline & Mean & SD & 2 & 3 & 4 & 5 & 6 & 7 & 8 \\
\hline 1. Kaizen completion & 0.36 & 0.22 & $\begin{array}{l}0.47 \\
n=6\end{array}$ & $\begin{array}{r}0.02 \\
n=12\end{array}$ & $\begin{array}{c}0.49 \text { * } \\
\mathrm{n}=12\end{array}$ & $\begin{array}{c}0.49 \text { * } \\
n=12\end{array}$ & $\begin{array}{r}0.25 \\
\mathrm{n}=12\end{array}$ & $\begin{array}{l}-0.62 \text { ** } \\
n=12\end{array}$ & $\begin{array}{r}-0.11 \\
\mathrm{n}=12\end{array}$ \\
\hline 2. Personal initiative (OP) & 3.23 & 0.74 & & $\begin{array}{r}-0.33 \\
n=7\end{array}$ & $\begin{array}{l}0.05 \\
n=7\end{array}$ & $\begin{array}{l}0.48 \\
n=7\end{array}$ & $\begin{array}{r}-0.24 \\
n=7\end{array}$ & $\begin{array}{r}-0.33 \\
n=7\end{array}$ & $\begin{array}{l}0.05 \\
n=7\end{array}$ \\
\hline 3. Personal initiative (MG) & 0.44 & 0.17 & & & $\begin{array}{l}-0.88 \\
n=14\end{array}$ & $\begin{array}{r}0.48 \\
n=14\end{array}$ & $\begin{array}{r}0.01 \\
\mathrm{n}=14\end{array}$ & $\begin{array}{l}-0.17 \\
n=14\end{array}$ & $\begin{array}{r}-0.07 \\
n=14\end{array}$ \\
\hline 4. Degree or organic structure & 3.82 & 0.90 & & & & $\begin{array}{c}0.48 \text { * } \\
\mathrm{n}=14\end{array}$ & $\begin{array}{c}0.60^{\text {** }} \\
n=14\end{array}$ & $\begin{array}{l}-0.54^{\text {** }} \\
\mathrm{n}=14\end{array}$ & $\begin{array}{l}-0.31 \\
n=14\end{array}$ \\
\hline 5. Degree of Clan org. culture & 25.47 & 10.80 & & & & & $\begin{array}{r}0.25 \\
\mathrm{n}=14\end{array}$ & $\begin{array}{l}-0.49 \text { * } \\
n=14\end{array}$ & $\begin{array}{l}-0.42 \\
n=14\end{array}$ \\
\hline 6. Degree of Clan org. culture & 16.50 & 8.17 & & & & & $\mathrm{n}=14$ & $\begin{array}{l}-0.49 \text { * } \\
n=14\end{array}$ & $\begin{array}{l}-0.20 \\
n=14\end{array}$ \\
\hline 7. Degree of Clan org. culture & 29.62 & 9.07 & & & & & & & $\begin{array}{l}-0.13 \\
n=14\end{array}$ \\
\hline 8. Degree of Clan org. culture & 25.92 & 11.37 & & & & & & & \\
\hline
\end{tabular}

measure and it has a significant relationship with the kaizen completion. It suggests that personal initiative may be good a proxy for measuring kaizen completion.

Hypothesis 2: The second hypothesis states that a more organically oriented organization structure is positively related to kaizen transfer success. In other words, it will be easier for organically structured companies to implement kaizen than for mechanistic firms. It was found that there was a significant relationship between the kaizen completion and degree of organic organizational structure, $\tau=0.49, n=12, p$ (one-tailed) $<0.05$. Thus, the data supports the hypothesis.

One way of interpreting this finding is that one of the major reasons why Japanese companies have been facing difficulties with transferring kaizen abroad is because of different organization structures in countries outside of Japan. Hayashi's (1994) research shows that the Japanese companies in general have more of an organic structure than that of non-Japanese companies. It can also explain why Japanese companies who set up plants abroad prefer greenfield investments rather than joint-ventures. In greenfield investments, the Japanese can develop an organic organizational structure from the start and they do not need to deal with changing an initially more mechanistic oriented organizational structure.
Hypothesis 3a, b, c, and d: The last set of hypothesis related to the influence of organization culture. Hypothesis H3a predicts that a clan culture leads to higher success with kaizen transfer. The hypothesis was confirmed, i.e. clan culture was significantly related to kaizen completion, $\tau=0.49$, $n=12, p$ (one-tailed) $<0.05$. Hypothesis $3 \mathrm{~b}$ predicts that an adhocracy organization culture leads to higher success with kaizen transfer. The results indicate that there is indeed a positive correlation between adhocracy culture and kaizen completion. However, this relationship was found not significant, i.e. the hypothesis was rejected. Hypothesis $3 \mathrm{c}$ predicts that a hierarchical organization culture leads to less success with kaizen transfer. This hypothesis was confirmed, i.e. hierarchical culture was related negatively and significantly to kaizen completion, $\tau=-0.62, n=12$, $\mathrm{p}$ (one-tailed) $<0.01$. Lastly, hypothesis $3 \mathrm{~d}$ predicted that a market organization culture leads to less success with kaizen transfer. Similar to hypothesis $3 \mathrm{~b}$, the correlation (negative) between a market culture and kaizen completion was confirmed but the relationship was found not significant. Thus the hypothesis was rejected.

These result show that organizations with a clan culture are more likely to be successful with 
kaizen transfer whereas a hierarchical culture does not fit well with kaizen development. It also indicates that what affects the successful kaizen transfer is whether a company has a flexibility orientation or a control orientation and not whether it has an internal or external dimension. Similar to the findings on organization structure, it can be inferred that one of the main reasons that Japanese companies are facing difficulties with transferring kaizen abroad could be the differences related to organization culture. Changing the culture is considered more difficult than changing the structure because it is related to people's belief. This is furthermore influenced by the national culture and history. The clan oriented culture is especially difficult to develop in nations with a more individualistic oriented national culture (Hofstede, 2001). The Netherlands is an example of such a country. There is also evidence in previous studies that Japanese companies try to hire personnel who possess a cooperative attitude and a motivation for solving problem within teams (Oliver \& Wilkinson, 1992; Shimada, 1990) and for example Recht \& Wilderom (1998) who mentioned that the Japanese prefer to hire individuals without previous work experience ('uncontaminated' labor). These activities can be interpreted as Japanese companies trying to set the necessary conditions for developing a clan culture or for changing towards a clan oriented culture.

\section{Conclusions}

This study examined the successful implementation of kaizen by Japanese companies in Europe, i.e. the Netherlands. The purpose of this study was to provide additional insight into factors that affect the successful international transfer of kaizen. More specifically, in this study a proxy for measuring kaizen was proposed and the influence of organization structure and organization culture was discussed. This led to several hypotheses. First, successful kaizen transfer is positively associated with personal initiative (H1). Second, successful kaizen transfer is positively related to organic firms (H2). Lastly, clan and adhocracy organizational culture lead to positive (H3a, H3b) and control-oriented and market culture lead to negative kaizen outcomes (H3c, H3d). The results confirmed H1, H2, H3a, and $\mathrm{H} 3 \mathrm{c}$ but $\mathrm{H} 3 \mathrm{~b}$ and $\mathrm{H} 3 \mathrm{~d}$ were rejected.

This research contributes to both theory and practice. It provides to the existing theories on kaizen by adding clarity to the concept of kaizen. It was found that personal initiative is correlated with kaizen. Thus, future research on kaizen may want to consider adopting measuring personal initiative as a proxy for kaizen. The study also suggests that difficulties of transferring kaizen abroad are related to organization structure and organization culture. In other words, the type of structure and the type of culture of the organization which is adopting kaizen influences whether it will be successful in transferring kaizen.

For the practical perspective, this study provides direction to practitioners who want to transfer kaizen abroad. Based on the study results, it is easier to transfer kaizen to organizations which are organic and which have a clan culture. In situations where these conditions do not exist managers can strive to either create those conditions (greenfield investments may be appropriate) or otherwise they should anticipate a more lengthy transfer process.

Some limitations exist for this exploratory research. First, in some sample companies, there were issues with the reliability of the organizational structure and culture data because data was gathered from a limited number of respondents. Second, the small sample size restricted the use of more sophisticated statistical analyses and therefore generalizability should be cautioned. Third, the use of subjective measures such as for measuring operator level personal initiative leaves open the possibility that respondents may have answered certain questions in what they believed were socially desirable or managerially appropriate manners. Although precautions were taken to minimize response bias by cross checking the data that are provided by respondents in the different level in the organization, social desirability bias may have nonetheless affected the findings. Fourth, the research design was cross-sectional. Thus, causeeffect relationship cannot be definitively inferred from the research results. 


\section{References}

Adler, P. S., Goldoftas, B., \& Levine, D. (1998). Stability and Change at NUMMI. In R. Boyer, E. Charron, U. Jürgens \& S. Tolliday (Eds.), Between Imitation and Innovation, the Transfer and Hybridization of Productive Models in the International Automobile Industry (pp. 128-161). Oxford: Oxford University Press.

Aoki, K. (2008). Transferring Japanese kaizen activities to overseas plants in China. International Journal of Operations and Production Management, 28(6), 518-539.

Aoki, M. (1988). Information, Incentives, and Bargaining in the Japanese Economy. Cambridge, New York, Port Chester, Melbourne, and Sydney: Cambridge University Press.

Bessant, J., Caffyn, S., \& Gallagher, M. (2001). An evolutionary model of continuous improvement behaviour. Technovation, 21(2), 67-77.

Besser, T. L. (1996). Team Toyota: Transplanting the Toyota Culture to the Camry Plant in Kentucky. Albany, NY: State University of New York.

Bhuiyan, N \& Baghel, A. (2005) An overview of continuous improvement: from the past to the present. Management decision, 43, 761 .

Blau, P. M. (1968). The Hierarchy of Authority in Organizations. The American Journal of Sociology, 73(4), 453-467.

Brunet, A. P., \& New, S. (2003). Kaizen in Japan: an empirical study. International Journal of Operations and Production Management, 23(12), 1426-1446.

Burns, T., \& Stalker, G. M. . (1961). The Management of Innovation. London: Tavistock.

Cameron, K. S., \& Quinn, R. E. . (2006). Diagnosing and Changing Organizational Culture: Based on the Competing Values Frameworks (Revised ed.). San Francisco: JosseyBass.

Claver, E., Tari, J. J., \& Molina, J. F. (2003). Critical factors and results of quality management: an empirical study. Total quality management $\mathcal{E}$ business excellence, 14(1), 155-157.

Cole, R. E. (1979). Work, Mobility \& Participation: A comparative study of American and Japanese industry. Berkeley and Los Angels: University of California press.

Covin, J. G., \& Slevin, D. P. (1988). The influence of organization structure on the utility of an entrepreneurial top management style. The Journal of management studies, 25(3), 217.

Deming, W. E. (2000). The new economics: For industry, government, education. Cambridge, MA: MIT press.

Deutsch, M. (1949). A theory of co-operation and competition. Human Relations, 2(2), 129.

Dobosz-Bourne, D., \& Jankowicz, A. D. (2006). Reframing resistance to change: experience from General Motors Poland. International Journal of Human Resource Management, 17(12), 2021-2034.
Douglas, T. J., \& Judge, J. W. Q. (2001). Total Quality Management Implementation and Competitive Advantage: The Role of Structural Control and Exploration. The Academy of Management Journal, 44(1), 458-169.

Frese, M., \& Fay, D. (2000). Measuring Personal Initiative Training Personal Initiative. Univeritat Giessen.

Frese, M., Fay, D., Hilburger, T., Leng, K., \& Tag, A. (1997). The concept of personal initiative: Operationalization, reliability and validity in two German samples. Journal of Occupational \& Organizational Psychology, 70(2), 139161.

Frese, M., Kring, W., Soose, A., \& Zempel, J. (1996). Personal Initiative at Work: Differences between East and West Germany. The Academy of Management Journal, 39(1), 3763.

Fukuda, K. J. (1988). Japanese Style Management Transferred: The Experience of East Asia. New York: Routledge.

Hayashi, K. (1994). Ibunka Inter face keiei (Intercultural management). Tokyo: Nihon Keizai Shinbunsha.

Hofstede, G. (2001). Culture's consequences: Comparing values, behaviors, institutions, and organizations across nations. Thousand Oak, CA: Sage Publications, Inc.

Hollander, M., \& Wolfe, D. A. (1999). Nonparametric Statistical Methods. New York: John Wiley \& Sons.

Hong, J.F.L., Snell, R.S. \& Easterby-Smith, M. (2006). Crosscultural influences on organizational learning in MNCS: The case of Japanese companies in China. Journal of International Management, 12, 408-429.

Imai, M. (1986). Kaizen: The Key to Japanese Competitiveness Success. New York: Random House Business Division.

Inkson, J. H. K., Pugh, D. S., \& Hickson, D. J. (1970). Organization Context and Structure: An Abbreviated Replication. Administrative Science Quarterly, 15(3), 318329.

Johnson, D. W. (1981). Effects of Cooperative, Competitive, and Individualistic Goal Structures on Achievement: A Meta-Analysis. Psychological Bulletin, 89(1), 47-62.

Jørgensen, F., Boer, H., \& Geretsen, F. (2003). Jump-starting continuous improvement through self-assessment. International Journal of Operations and Production Management, 23(10), 1260-1278.

Kenney, M., \& Florida, R. L. (1993). Beyond mass production: The Japanese system and its transfer to the US. New York, Oxford: Oxford University Press.

Khandwalla, P. N. (1977). The design of organizations. New York: Harcourt.

Koike, K. (1998). NUMMI and Its Prototype Plant in Japan: A Comparative Study of Human Resource Development at the Workshop Level. Journal of the Japanese and International Economies, 12(1), 49-74.

Kono, T. (1982). Japanese management philosophy: can it be exported? Long Range Planning, 15(3), 90-102. 
Liker, J. K. (2004). The Toyota way: 14 management principles from the world's greatest manufacturer New York: McGrawHill.

Lillrank, P. (1995). The Transfer of Management Innovations from Japan. Organization Studies, 16(6), 971.

Malloch, H. (1997). Strategic and HRM aspects of kaizen: a case study. New technology, work, and employment, 12(2), 108.

Monden, Y. (1994). Toyota Production System: An integrated approach to Just-In-Time (2nd ed.). London: Chapman \& Hall.

Ohmae, K. (1985). Triad power, The coming shape of global competition. New York, N.Y.: The Free Press.

Ohno, T. (1988). Toyota production system: beyond large-scale production. New York, NY: Productivity Press.

Oliver, N., \& Wilkinson, B. (1992). The Japanization of British industry. Oxford UK and New York, NY: Blackwell Oxford.

Osono, E., Shimizu, N., Takeuchi, H., \& Dorton, J. (2008). Extreme Toyota: Radical Contradictions that Drive Success at the World's Best Manufacturer. New Jersey: John Wiley \& Sons.

Ouchi, W. G., \& Jaeger, A. M. (1978). Type Z Organization: Stability in the Midst of Mobility. The Academy of Management Review, 3(2), 305.

Pugh, D. S., Hickson, D. J., Hinings, C. R., \& Turner, C. (1968). Dimensions of Organization Structure. Administrative Science Quarterly, 13(1), 65-105.

Quinn, R. E., \& Rohrbaugh, J. (1981). A Competing Values Approach to Organizational Effectiveness. Public Productivity Review, 5(2), 122-140.
Quinn, R. E., \& Spreitzer, G. M. (1991). The psychometrics of the competing values culture instrument and an analysis of the impact of organizational culture on quality of life. Research in organizational change and development, 5(1), 115142.

Recht, R., \& Wilderom, C. (1998). Kaizen and culture: on the transferability of Japanese suggestion systems. International Business Review, 7(1), 7-22.

Reimann, B. C. (1974). Dimensions of Structure in Effective Organizations: Some Empirical Evidence. The Academy of Management Journal, 17(4), 693-708.

Saka, A. (2004). The Cross-National Diffusion of Work Systems: Translation of Japanese Operations in the UK. Organization Studies 25(2), 209.

Shimada, H. (1990). The economics of humanware: Humanware no keizaigaku: America no naka no nihon kigyo. Tokyo: Iwanami shoten

Styhre, A. (2001). Kaizen Ethics, and care of the operations: management after empowerment. Journal of Management Studies, 38(6), 795-810.

Taylor, B. Japanese management style in China? Production practices in Japanese manufacturing plants. New Technology, Work and Employment, 14(2), 129-142.

Wakamatsu, Y. (2007). Toyota shiki Kaizen no susume kata: Saikyo no Gemba wo tsukuri ageru. Tokyo: PHP Business

White, M. R. M., \& Trevor, M. (1983). Under Japanese management: the experience of British workers. London: Heinemann Educational Publishers.

Kodo Yokozawa is a PhD candidate at the University of Twente in the School of Management and Governance. His research interest is international Japanese management systems transfer, focusing on transfer of kaizen (continuous improvement) activities. He received his MBA from Eastern Washington University, USA.

Harm-Jan Steenhuis is a professor of Operations Management at Eastern Washington University and Chair of the Department of Management. He received his MSc in Industrial Engineering and Management and his PhD in International Technology Transfer from the University of Twente, the Netherlands. He is currently involved in research on international technology transfer and manufacturing, industry-university technology transfer and instructor-student knowledge transfer.

Erik J. de Bruijn is a professor of International Management. He received his MSc from the University of Massachusetts and a PhD from the University of Twente. Since 1971 he worked as project coordinator and consultant for the Netherlands Government in various industrialization projects in developing countries. Currently he teaches International Business Management at the School of Management and Governance, University of Twente. 